\title{
APLIKASI PENGENALAN CANDI-CANDI PADA PROVINSI JAWA TIMUR MENGGUNAKAN AUGMENTED REALITY BERBASIS ANDROID
}

\author{
Irgi Yoga Pratama ${ }^{1}$ Suryo Adi Wibowo ${ }^{2}$ Yosep Agus Pranoto ${ }^{3}$ \\ Program Studi Teknik Informatika S1, Fakultas Teknologi Industri \\ Institut Teknologi Nasional Malang, Jalan Raya Karanglo km 2 Malang, Indonesia \\ Irgiyoga46@gmail.com
}

\begin{abstract}
ABSTRAK
Candi berasal dari salah satu nama untuk Durga sebagai Sewi Maut yaitu Candika. Dalam mitologi Hindu Dewa Durga sebagai Dewi Maut yang dihubungkan dewa kematian, jadi candi adalah sebuah bangunan untuk memuliakan orang yang telah meninggal. Khususnya untuk para raja dan orang orang terkemuka.

Untuk saat ini pengetahuan tentang candi masih sangat minim, dengan keterbatasan media untuk dipelajari. Candi memiliki ragam relief dengan struktur bagunan kuno yang memiliki sejarah tersediri. Walaupun candi sudah sangat kuno, Candi merupakan salah satu media pembelajaran dalam ilmu sejarah dan ilmu sosial yang dapat dipelajari oleh berbagai kalangan dari akademis maupun non-akademis.

Hasil pengujian jarak $10 \mathrm{~cm}$ sampai $80 \mathrm{~cm}$ marker dapat terdeteksi dengan cepat dan objek muncul dalam satuan waktu 1 hingga 2 detik. Sedangkan pada rentang jarak $90 \mathrm{~cm}$ dan $100 \mathrm{~cm}$ marker tetap bias terdeteksi namun sedikit lebih lambat dalam memunculkan objek yang diperlukan waktu 3 hingga 5 detik. Kemudia pada rentang jarak $110 \mathrm{~cm}$ dan $120 \mathrm{~cm}$ marker tidak terdeteksi. Pengujian Cahaya Lampu dapat terdeteksi pada lampu LED 3 watt, 5 watt, dan 30 watt. pengujian aplikasi pada 10 responden hasil yang didapatkan adalah nilai indeks $84,6 \%$ yang menandakan bahwa responden "Sangat Setuju" dengan keseluruhan pertanyaan yang diberikan. Pengujian berdasarkan sudut marker Sudut $0^{\circ}$ hingga Sudut $50^{\circ}$ marker dapat terdeteksi dengan cepat dan lancar, sedangkan untuk Sudut $60^{\circ}$ dan Sudut $70^{\circ}$ marker dapat terdeteksi namun sedikit melamban waktu pendeteksian oleh aplikasi, dan pada Sudut $80^{\circ}$ dan Sudut $90^{\circ}$ marker tidak dapat terdeteksi.
\end{abstract}

Kata kunci : Augmented Reality, Candi, Hasil Pengujian.

\section{PENDAHULUAN}

\subsection{Latar Belakang}

Candi berasal dari salah satu nama untuk Durga

sebagai Sewi Maut yaitu Candika. Dalam mitologi Hindu Dewa Durga sebagai Dewi Maut yang dihubungkan dewa kematian, jadi candi adalah sebuah bangunan untuk memuliakan orang yang telah meninggal. Khususnya untuk para raja dan orang orang terkemuka. Dalam arti bukan orang yang meninggal dikuburkan dalam candi, melainkan bermacam-macam benda yang dinamakan pripih dan dianggap sebagai lambang zat-zat jasmaniah dari sang raja yang telah bersatu kembali dengan dewa penitisnya. Sedangkan mayat dari seorang raja tersebut dibakar dalam sebuah upacara ritual, abu tersebut dihanyutkan ke laut. [1]

Untuk saat ini pengetahuan tentang candi masih sangat minim, dengan keterbatasan media untuk dipelajari. Candi memiliki ragam relief dengan struktur bagunan kuno yang memiliki sejarah tersediri. Walaupun candi sudah sangat kuno, Candi merupakan salah satu media pembelajaran dalam ilmu sejarah dan ilmu sosial yang dapat dipelajari oleh berbagai kalangan dari akademis maupun nonakademis. Media belajar untuk candi masih banyak yang menggunakan media cetak buku, media internet dengan menampilkan visual candi yang masih disajikan dalam bentuk 2D (2 Dimensi) atau datang ke tempat lokasi candi berada. Untuk melihat secara nyata bentuk dari candi dan sejarah candi berdasarkan sejarahwan setempat, yaknin dilakukan dengan cara mendatangi lokasi candi tersebut berada, yang jarak tempuh tempat candi dari satu ke candi lain yang terbilang cukup jauh dan relatif membuang banyak waktu.

Permasalahan tersebut menjadi latar belakang dilakukannya pengembangan dan pembuatan media pembelajaran berbasis Agumented Reality untuk pengenalan candi yang dapat digunakan untuk sarana belajar yang baru dan interaktif. Selain lebih interaktif, informasi candi yang di tampilkan merupakan perwujudan baru dalam belajar. Pembelajaran menggunakan Augmented Reality bersifat interaktif, immersion (memasukkan), realtime (secara langsung) dan berisikan informasi yang jelas dalam bentuk 3D. Augmented Reality yang dikemas secara praktis karena semua informasi yang dibutuhkan dijadikan menjadi sebuah aplikasi tunggal dan dapat di gunakan kapan pun. Karena pembelajaran Augmented Reality candi menjadi lebih menarik, interaktif, dan praktis bisa meningkatkan semangat belajar orang yang berminat serta meningkatkan pengetahuan tentang candi mulai dari kalangan umum hingga kalangan akademis.

\subsection{Rumusan Masalah}

Berdasarkan permasalahan yang sudah dipaparkan pada latar belakang, maka dapat dirumuskan masalah sebagai berikut: 
1 Bagaimana cara merancang dan mengimplementasikan aplikasi media pembelajaran pengenalan candi di provinsi Jawa Timur berbasis sistem operasi mobile Android?

2 Bagaimana menerapkan teknologi Augmented Reality pada aplikasi Android sebagai media pembelajaran yang menarik?

3 Bagaimana cara membuat marker dengan vuforia serta membuat aplikasinya menggunakan software Unity dan membuat objek 3D candi menggunakan blender?

\subsection{Tujuan Penelitian}

Terdapat beberapa tujuan dari pembuatan aplikasi ini sebagai berikut :

1. Mempermudah kalangan umum dan akademis untuk mengetahui informasi tentang candi dalam area Jawa Timur.

2. Salah satu cara untuk melakukan proses pembelajaran candi dengan interaktif pada media elektronik.

3. Sebagai sarana aplikasi mobile berbasis android dan sebagai media pembelajaran yang interaktif dengan memvisualisasikan objek candi 2D menjadi objek candi 3D dengan memanfaatkan teknologi Augmented Reality.

\subsection{Batasan Masalah}

Berdasarkan rumusan masalah pembuatan aplikasi ini terdapat beberapa batasan dalam pembuatan yaitu sebagai berikut:

1. Aplikasi media pembelajaran berbasis mobile dengan menggunakan sistem operasi Android.

1. Aplikasi ini di kembangkan menggunakan software Unity3d, vuforia dan blender.

2. Bahasa aplikasi yang di gunakan yaitu bahasa Indonesia.

3. Target pengguna yaitu kalangan umum \& akademis.

4. Sumber data dari E-Book Ragam Hias CandiCandi di Jawa.

5. Materi di aplikasi berisikan ragam hias candi, bentuk candi.

6. Objek 3 dimensi candi berjumlah 10 objek..

\section{TINJAUAN PUSTAKA}

\subsection{Penelitian Terkait}

Berdasarkan penilitan yang dilakukan Syahrin dan kawan-kawan pada tahun 2016, Metode Marker Based Tracking yaitu memunculkan objek berdasarkan beberapa parameter antara jarak terhadap pixel dan jarak terhadap warna. Parameter parameter tersebut memiliki variasi nilai jarak yaitu $5 \mathrm{~cm}, 10 \mathrm{~cm}$, $20 \mathrm{~cm}, 30 \mathrm{~cm}, 40 \mathrm{~cm}, 50 \mathrm{~cm}$ sebagai sub indikator jarak pendeteksian. Sedangkan nilai resolusinya yaitu 32x50px, 64x100px, 96x150px untuk sub indikator pixel dan filter RGB sebagai sub indikator warna dengan pengujian jarak minimun dan jarak maksimum terhadap pixel dan warna. [2]

Ditahun yang sama yaitu 2016, penelitian yang dilakukan oleh Siswanti dan kawan-kawan, Augmented Reality (AR) merupakan proses penggabungan video atau photographi display dengan melapisi gambar memanfaatkan pembangkit data computer. Augmented Reality memiliki karkateristik sistem sebagai menggabungkan dunia nyata dan dunia virtual, berjalan interaktif secara Real-time dan intregrasi dalam 3 Dimensi. Augmented Reality dapat diklasifikasikan menjadi 2 metode yaitu dengan marker dan tanpa marker (markerless). [3]

Berdasarkan penilitian yang dilakukan oleh Pramono dan kawan-kawan pada tahun 2019 Augmented Reality merupakan sebuah teknologi yang mampu menggabungkan benda maya dua dimensi atau tiga dimensi kedalam sebuah lingkungan nyata kemudian memproyeksikannya.[4]

Barkah dan kawan-kawan di tahun 2017, Malang merupakan daerah yang dapat ketahui dengan banyak wisata yang ada di daerah tersebut contohnya seperti bagunan peninggalan kerajaan yaitu candi, terdapat beberapa candi yang belum terlalu terkenal di kalangan masyarakat, sehingga dikhawatirkan mengingat generasi muda penerus bangsa harus menjaga dan melestarikan budaya leluhurnya.[5]

Ditahun yang sama Rajmah dan kawan kawan menyebutkan Unity merupakan satu dari sekian banyak game engine atau mesin pembuat game serta perangkat lunak lainnya. Dengan software ini membuat game sendiri dapat dilakukan dengan lebih mudah dan cepat, hebatnya lagi Unity mendukung pembuatan game atau perangkat lunak lain dalam berbagai macam platform, missal seperti Unity Web, Windows, Mac, Andorid, iOs, Xbox, Playstation 3 dan Wii.[5]

Pada tahun 2019 Novitasari menggabungkan teknologi Augmented Reality terhadap suatu barang yang ada di dunia nyata dan memproyeksikannya menggunakan media elektronik, dengan memanfaatkan teknologi ini tercipatalah aplikasi pengenalan senjata tradisional Indonesia dapat meningkatkan minat belajar siswa tentang kebudayaan dan sejarah di Indonesia, tetapi tak lepas juga memberikan ilustrasi atau gambaran bentuk asli dari objek senjata.[6]

\subsection{Dasar teori}

\subsubsection{Augmented Reality}

Teknologi augmented reality merupakan salah satu trobosan yang digunakan pada akhir - akhir ini untuk bidang interaksi. Penggunaan teknologi ini akan sangat membantu dalam menyampaikan informasi kepada pengguna. Augmented Reality merupakan teknologi interaksi yang menggabungkan dunia nyata dan dunia maya. [7]

Metode yang dikembangkan pada Augmented Reality saat ini terbagi menjadi dua metode, yaitu 
Marker Based Tracking dan Markless Augmented Reality. [8]

\subsubsection{Android}

Android adalah sebuah sistem operasi yang dirancang oleh Google yang berbasiskan kernel Linux dan berbagai perangkat lunak Open Source lainnya serta biasa digunakan untuk perangkat dengan layar sentuh seperti smartphone dan tablet.[9]

Telepon pertama yang memakai sistem operasi Android adalah HTC Dream, yang dirilis pada 22 Oktober 2008. Pada penghujung tahun 2009 diperkirakan di dunia ini paling sedikit terdapat 18 jenis telepon seluler yang menggunakan Android.[10]

\subsubsection{Vuforia SDK}

Vuforia merupakan Augmented Reality Software Development Kit (SDK). Vuforia SDK memungkinkan pengembangan Augmented Reality pada perangkat mobile. Vuforia dulunya juga dikenal dengan QCAR (Qualcomm Company Augmented Reality). Vuforia menggunakan teknologi Computer Vision untuk mengenali dan melacak gambar planar (Target Image). Kelebihan dari kemampuan pengolahan Qualcomm Augmented Reality yaitu Teknologi Computer Vision digunakan untuk menyeimbangkan gambar yang tercetak dan objek 3D. Yang kedua Mendukung beberapa tools development (Eclipse, Android, Xcode) Vuforia menyediakan Application Programming Interface (API) di C++, Objective-C, Java. Vuforia SDK mendukung pembangunan aplikasi untuk platform Android dan iOS. [11]

\subsubsection{Image Target}

Image Target adalah gambar yang bisa dilacak dan dideteksi oleh Vuforia SDK. Vuforia SDK mengaplikasikan algoritma khusus untuk mendeteksi dan melacak fitur yang secara natural ditemukan didalam sebuah gambar. Vuforia SDK mengenali image target dengan membandingkan fitur yang ada pada gambar fisik dengan gambar yang ada didalam database aplikasi. Ketika gambar terdeteksi, SDK akan melacak gambar selama berada di sudut pandang kamera. Fitur yang dilacak oleh Vuforia SDK adalah detail berbentuk sudut pada gambar. Gambar yang akan digunakan sebagai image target harus memiliki beberapa kriteria pembuatan image target yaitu:

1. Memiliki format 8 atau 16 -bit dan JPG atau PNG.

2. Gambar berformat JPG/PNG harus memiliki warna RGB atau grayscale

3. Memiliki resolusi minimal 320 pixel.

4. Memiliki ukuran maksimal $2 \mathrm{MB}$.

5. Gambar tidak memiliki pola yang berulang.

Setelah diunggah, secara otomatis gambar mendapatkan implementasi algoritma yang dibuat khusus oleh vuforia sehingga fitur-fitur bisa terlihat dengan jelas. [12]

\subsubsection{Blender}

Blender merupakan aplikasi pada komputer yang berguna untuk membuat animasi, efek visual, objek 3D, aplikasi interaktif dan game. Blender merupakan Open Source Software atau istilah lainnya software yang dapat digunakan di berbagai macam OS (Operating System) dan juga merupakan software yang terbuka untuk dipelajari, diubah, disebarluaskan. [13]

\subsubsection{Unity}

Unity adalah sebuah sebuah tool yang terintegrasi untuk membuat game, arsitektur bangunan dan simulasi. Unity bisa untuk games PC dan games Online. Untuk games Online diperlukan sebuah plugin, yaitu Unity Web Player. Unity tidak dirancang untuk proses desain atau modelling, dikarenakan unity bukan tool untuk mendesain. Jika ingin mendesain, pergunakan 3D editor lain seperti 3dsmax atau Blender. Banyak hal yang bisa dilakukan dengan unity. [14]

\subsubsection{Flowchart}

Flowchart adalah adalah suatu bagan dengan simbol-simbol tertentu yang menggambarkan urutan proses secara mendetail dan hubungan antara suatu proses (instruksi) dengan proses lainnya dalam suatu program.

Dalam perancangan flowchart sebenarnya tidak ada rumus atau patokan yang bersifat mutlak (pasti). Hal ini didasari oleh flowchart (bagan alir) adalah sebuah gambaran dari hasil pemikiran dalam menganalisa suatu permasalahan dalam komputer. Karena setiap analisa akan menghasilkan hasil yang bervariasi antara satu dan lainnya. Kendati begitu secara garis besar setiap perancangan flowchart selalu terdiri dari tiga bagian, yaitu input, proses dan output. [15]

\subsubsection{Candi}

Candi adalah bangunan suci tempat pemujaan dewa, dan dianggap merupakan replika Gunung Mahameru di India yang melambangkan alam semesta. Ajaran Hindu-Budha, menganggap Gunung Mahameru adalah gunung kosmos yang terletak di tengah kosmos sebagai poros dunia. Gunung tersebut berdiri mulai dari dasar bumi sampai ke puncak surga tertinggi, dan di puncak gunung inilah tempat bersemayamnya para dewa. Bangunan candi diketahui merupakan salah satu aspek budaya yang mendapat pengaruh dari India, walaupun istilah "candi" sendiri tidak berasal dari India. Masyarakat Jawa semula menyebut istilah candi untuk bangunan keagamaan atau kuil yang berasal dari Masa Klasik Indonesia. Istlah candi kemudian dipergunakan juga untuk menamakan bangunan-bangunan lain dari masa yang 
sama, meskipun bangunan tersebut bukan merupakan kuil, seperti: gapura/pintu gerbang, dan petirtaan/pemandian suci (Hardiati, 2002: 1). [16]

\section{METODE PENELITIAN}

\section{Desain Sistem Media Pembelajaran}

\subsubsection{Blok Diagram}

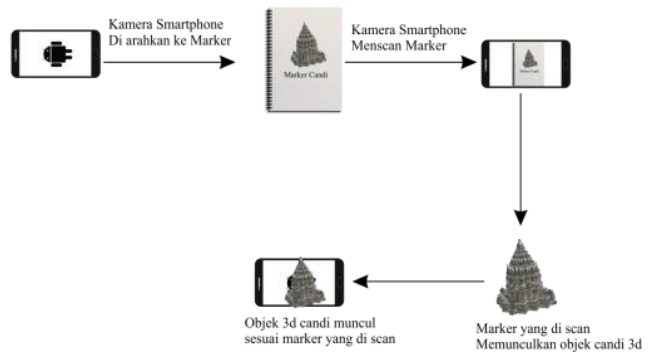

Gambar 1 blok diagram

Dalam Gambar 1 blok diagram sistem Augmented reality diatas menunjukan interaksi antara user dengan aplikasi ar candi. Ketika user mengakses aplikasi dan memilih fitur Scan Augmented reality, user diharuskan untuk mengarahkan kamera smartphone diatas gambar marker, setelah marker terdeteksi oleh kamera maka marker tersebut memanggil objek 3D sesuai dengan marker tersebut. Setelah dipanggil maka objek 3D ditampilkan di layar smartphone user.

\subsubsection{GUI Menu}

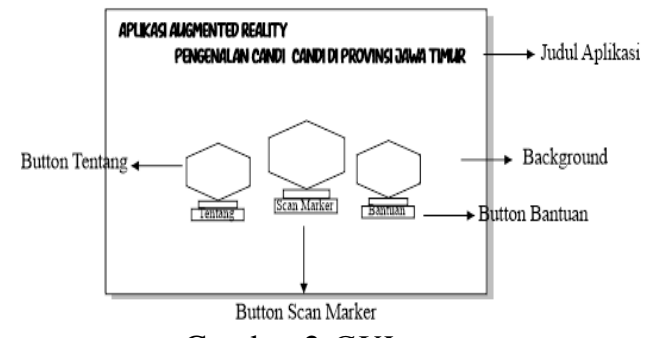

Gambar 2 GUI menu

Dilihat di gambar 2 GUI menu utama terlihat susunan dan tata letak menu aplikasi media pembelajaran tersebut dimana ada judul dan 3 button, button pertama Augmented Reality yakni scan marker yang berisi informasi objek 3D marker. Button kedua yakni yakni about dimana user melihat informasi berupa biodata pengembang aplikasi AR Candi. Button ketiga yakni Help dimana user akan melihat tata cara penggunaan aplikasi.

\subsection{Struktur Menu}

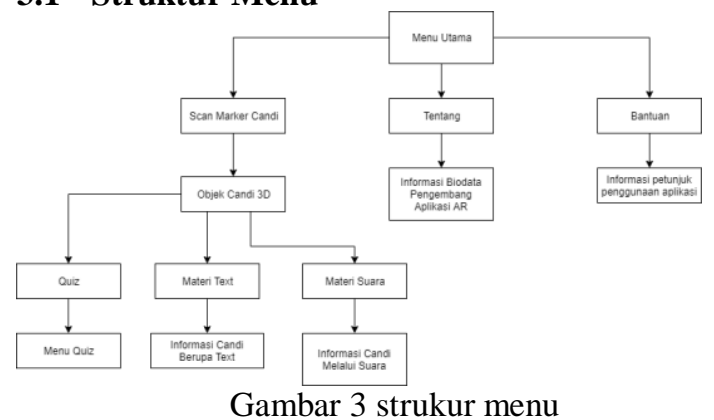

Pada gambar 3 Struktur menu diketahui Menu Utama Aplikasi di sediakan 3 tombol atau button dengan fungsi yang berbeda. Yang pertama yaitu tombol scan marker Candi untuk masuk kedalam tampilan men-scan marker dan dalam tampilan scan marker di tampilkan 2 tombol yaitu Deskripi untuk menampilkan informasi candi dalam sebuah tampilan, dan Suara untuk menampilkan informasi melalui media suara sebagai sarana penyampaian informasi. Yang kedua yaitu tombol Tentang dimana dalam tampilan tentang nantinya akan berisikan informasi tentang biodata pengembang aplikasi. Yang ketiga yaitu tombol Bantuan berfungsi untuk menampilkan tentang petunjuk untuk penggunaan aplikasi ARCandi.

\subsection{Flowchart Aplikasi Dan Metode 3.3.1 Flowchart Aplikasi}

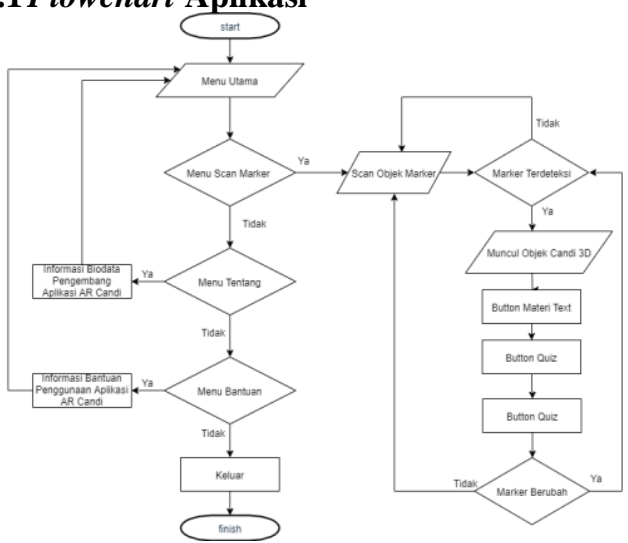

Gambar 4 Flowchart aplikasi

Dilihat digambar 4 Flowchart sistem diawali dengan start yaitu halaman awal saat membuka aplikasi, pada saat di menu utama user bisa memilih mulai dari scan marker yang berisi scan marker objek candi, pada halaman scan marker nanti user akan meletakkan objek marker di bawah posisi kamera. Jika marker sesuai dengan database maka objek Candi 3D akan muncul, jika tidak sesuai maka tidak muncul. Selanjutnya untuk Tentang, user akan diarahkan ke informasi biodata pengembang aplikasi AR. Dan pada Keluar, user akan menutup aplikasi AR kemudian End. 


\subsubsection{Flowchart Sistem}

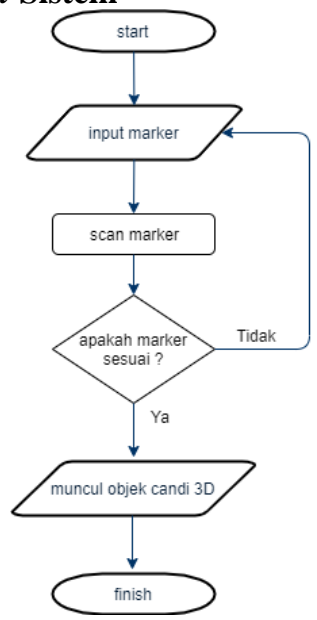

Gambar 5 Flowchart sistem

Pada gambar 5 Flowchart Proses berjalannya aplikasi Augmented Reality dimulai dengan membaca marker oleh kamera smartphone. Kemudian kamera akan mendeteksi dan mengidentifikasi marker dengan mencocokan pola marker tersebut. Jika marker tidak terdeteksi maka, user harus mengatur ulang identifikasi dengan kamera. Jika marker terdeteksi maka akan muncul objek 3D sesuai marker yang di deteksi.

\section{HASIL DAN PEMBAHASAN}

\subsection{Pengujian Menu Utama}

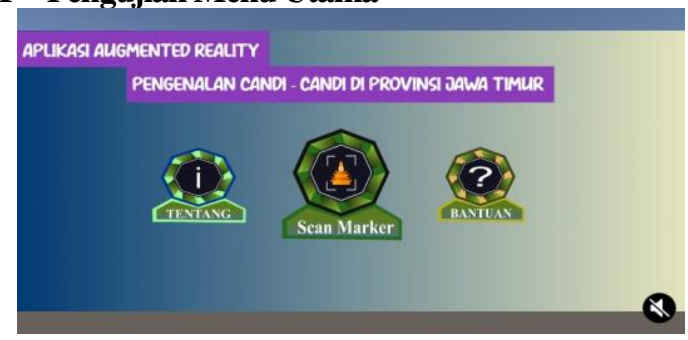

Gambar 6 Pengujian menu utama

Pada Gambar 6 Pengujian menu utama menunjukkan sebuah tampilan aplikasi dimana fitur dan tombol menu, mulai dari tombol materi, tombol augmented reality, tombol tentang, tombol bantuan.

\subsection{Pengujian Menu Materi}

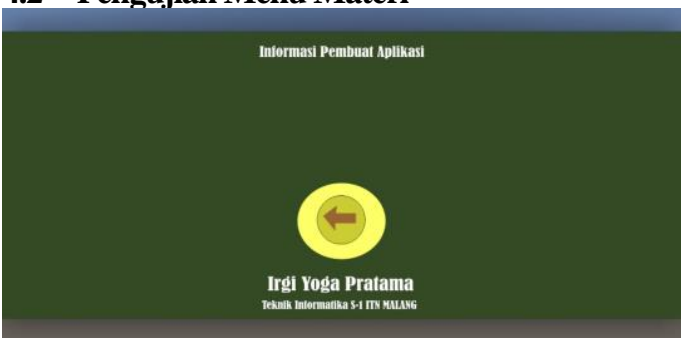

Gambar 7 Pengujian menu tentang

Pada Gambar 7 Pengujian menu tentang diatas menunjukkan tampilan dari menu tentang yang menampilkan biodata dari pembuat aplikasi.

\subsection{Pengujian Menu Bantuan}

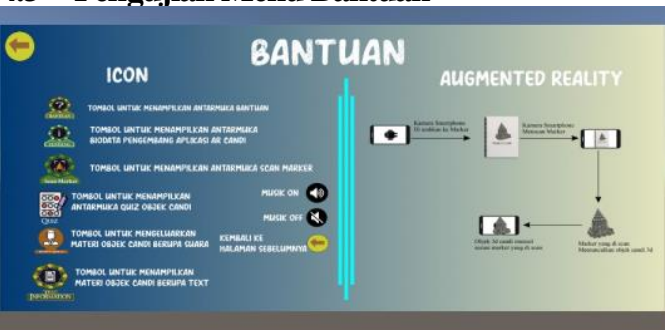

Gambar 8 Pengujian menu bantuan

Pada Gambar 8 Pengujian menu bantuan diatas menunjukkan tampilan dari menu bantuan, dimana menu bantuan ini berisikan informasi petunjuk dan tata cara penggunaan aplikasi.

\subsection{Pengujian Menu Augmented Reality}

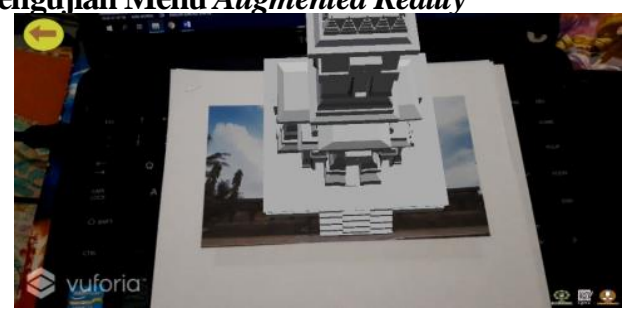

Gambar 9 Pengujian menu augmented reality

Pada Gambar 9 Pengujian augmented reality diatas menunjukkan tampilan menu augmented reality, tampilan tersebut menampilkan objek 3 dimensi candi beserta 3 tombol, yakni tombol kembali tombol Materi Text, Quiz, dan tombol narasi.

\subsection{Pengujian Latihan Soal}

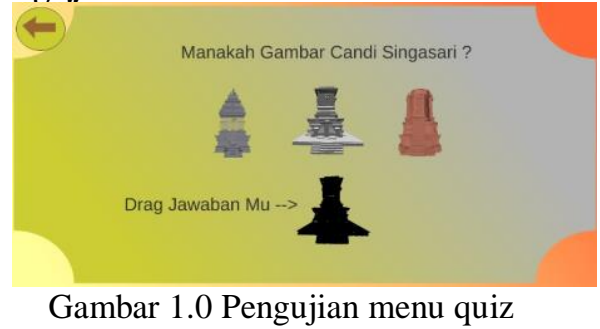

Pada Gambar 10 Pengujian quiz diatas menunjukkan tampilan menu quiz, tampilan tersebut menunjukkan pertanyaan dimana pengguna diharuskan memilih jawaban yanh tepat dan mengubah posisi objek ke tempat objek yang di tuju. Dari tampilan tersebut terdapat sebuah 3 objek candi. Jika pengguna pengguna menjawab benar maka objek candi tersebut menyatu dengan objek candi warna hitam.

\subsection{Pengujian Menu Materi Text}

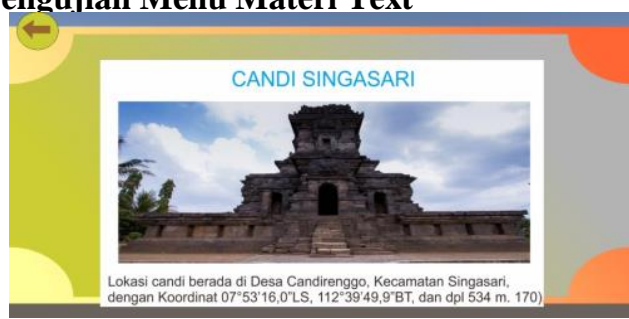

Gambar 11 Pengujian menu tentang 
Pada Gambar 11 Pengujian menu tampilan menu materi text, tampilan tersebut menunjukkan informasi materi secara text.

\subsection{Pengujian Deteksi Rentang Jarak}

Pada augmented reality, jarak merupakan salah satu faktor yang berpengaruh terhadap proses deteksi marker. Semakin jauh jarak marker terhadap kamera, maka semakin buruk kualitas pola marker yang dapat di proses oleh kamera pada aplikasi. Pengujian jarak ini bertujuan untuk mengetahui rentang jarak yang optimal agar marker dapat terdeteksi dengan baik.

Pengujian rentang jarak dilakukan dengan 10 rentangan jarak, yakni $10 \mathrm{~cm}, 20 \mathrm{~cm}, 30 \mathrm{~cm}, 40 \mathrm{~cm}$, $50 \mathrm{~cm}, 60 \mathrm{~cm}, 70 \mathrm{~cm}, 80 \mathrm{~cm}, 90 \mathrm{~cm}, 100 \mathrm{~cm})$.

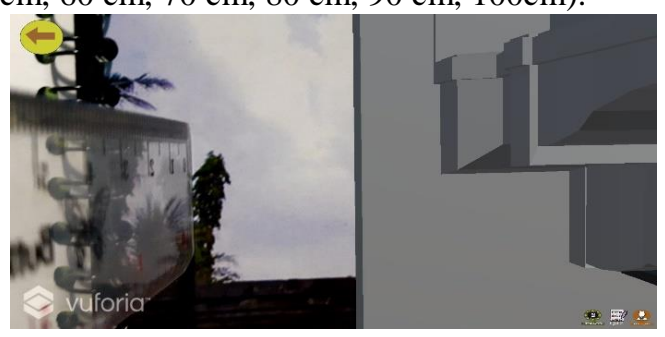

Gambar 12 jarak $10 \mathrm{~cm}$

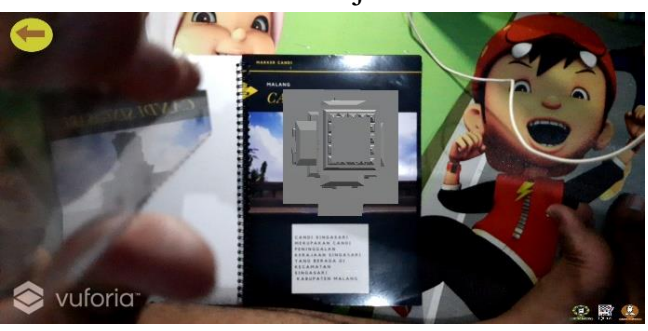

Gambar 13 jarak $60 \mathrm{~cm}$

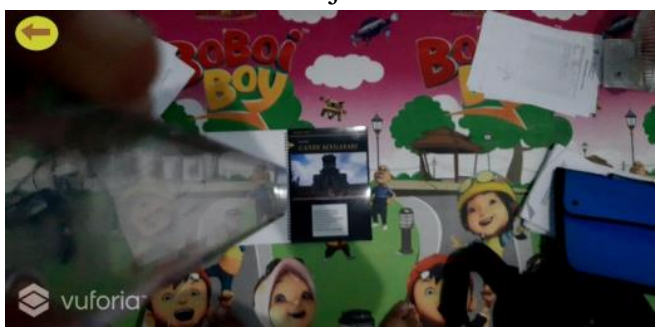

Gambar 14 jarak $120 \mathrm{~cm}$

Tabel 1 Pengujian jarak marker

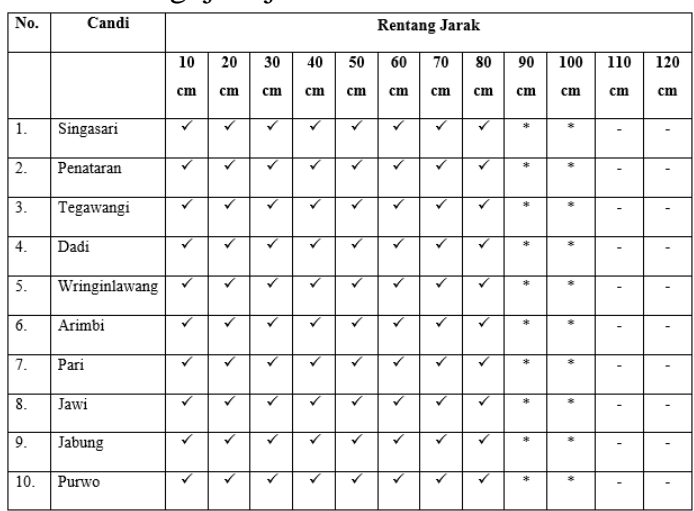

Uji coba marker dengan marker objek $3 \mathrm{~d}$ menggunakan 10 rentang jarak yakni jarak $10 \mathrm{~cm}$ hingga $100 \mathrm{~cm}$. Dengan hasil rentang jarak dekat 10 $\mathrm{cm}$ sampai $80 \mathrm{~cm}$ marker dapat terdeteksi dengan cepat dan objek muncul dalam satuan waktu 1 hingga 2 detik. Sedangkan pada rentang jarak $90 \mathrm{~cm}$ dan 100 $\mathrm{cm}$ marker tetap bias terdeteksi namun sedikit lebih lambat dalam memunculkan objek yang diperlukan waktu 3 hingga 5 detik. Kemudian pada rentang jarak $110 \mathrm{~cm}$ dan $120 \mathrm{~cm}$ marker $\neg$ tidak terdeteksi. Berhasil atau tidak nya marker di pindai tergantung oleh rating yang diberikan oleh vuforia saat mengupload target image, rating dinilai dari 1 hingga 5 dimana jika target image memiliki rating 0 , gambar marker tidak akan bisa digunakan, sedangkan semakin tinggi rating image target dari vuforia semakin cepat kamera menangkap marker yang di pindai.

\subsection{Pengujian Cahaya}

Pengujian intensitas cahaya dilakukan dengan menggunakan media watt dari lampu. Pengukuran kecerahan cahaya menggunakkan watt dari dari lampu yang akan di ujicoba yakni tanpa cahaya (gelap), lampu LED 3 watt, 5 watt, 30 watt. Hasil pengujian dapat dilihat pada tabel 2

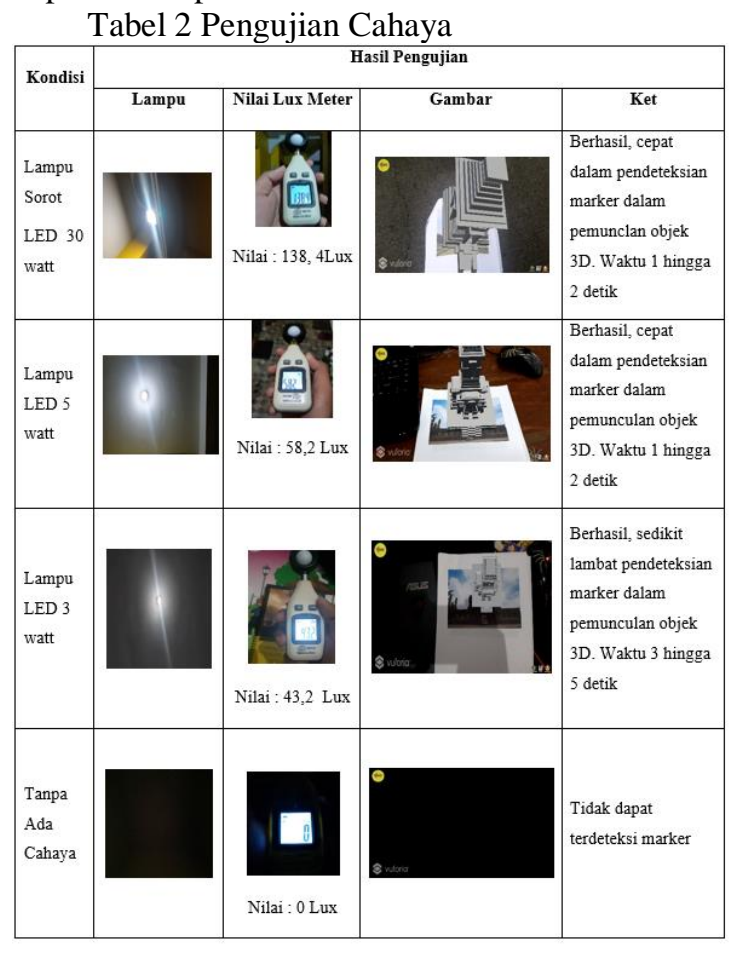

Dari hasil pengujian deteksi marker menggunakan intesitas cahaya didapatkan hasil pengujian semua marker tidak dapat terdeteksi ketika tanpa adanya cahaya, sedangkan dapat terdeteksi dengan baik menggunakan cahaya dari lampu LED 3 watt, 5 watt, dan 30 watt. Semakin terang cahaya dari lampu maka semakin mudah dan cepat waktu untuk mendeteksi marker, namun semakin redup cahaya dari lampu maka sedikit membutuhkan waktu lebih lama untuk mendeteksi marker.

\subsection{Pengujian User}

Pengujian User dilakukan untuk menilai kelayakan aplikasi pengenalan candi dengan mengumpulkan pendapat melalui kuisioner. Kuisioner 
menggunakan lima alternatife pilihan jawaban yaitu sangat setuju, setuju, netral, tidak setuju dan sangat tidak setuju. Terdapat 10 indikator penilaian. Hasil dari kuisioner dapat dilihat pada Tabel 3

Tabel 3 Pengujian user

\begin{tabular}{|c|l|c|c|c|c|c|c|c|}
\hline \multirow{2}{*}{ No } & \multicolumn{1}{|c|}{ Pertanyaan } & 5s & S & N & TS & STS & $\begin{array}{l}\text { Total } \\
\text { Nilai }\end{array}$ & $\begin{array}{l}\text { Index } \\
\%\end{array}$ \\
\hline 1. & Tampilan aplikasi menarik & 2 & 7 & 1 & - & - & 41 & $82 \%$ \\
\hline 2. & $\begin{array}{l}\text { Materi yang ditampilkan sesuai } \\
\text { dengan yang dipelajari }\end{array}$ & 4 & 4 & 2 & - & - & 42 & $84 \%$ \\
\hline 3. & $\begin{array}{l}\text { Objek tiga dimensi yang ditampilkan } \\
\text { sesuai dengan model candi asli }\end{array}$ & 3 & 6 & 1 & - & - & 42 & $84 \%$ \\
\hline 4. & $\begin{array}{l}\text { Aplikasi mempermudah dalam } \\
\text { mempelajari ragam hias candi dan } \\
\text { bentuk candi }\end{array}$ & 5 & 4 & 1 & - & - & 44 & $88 \%$ \\
\hline 5. & $\begin{array}{l}\text { Aplikasi dapat meningkatkan minat } \\
\text { belajar }\end{array}$ & 5 & 2 & 3 & - & - & 42 & $84 \%$ \\
\hline 6. & $\begin{array}{l}\text { Aplikasi memiliki petunjuk } \\
\text { pengoperasian yang jelas }\end{array}$ & 3 & 4 & 3 & - & - & 40 & $80 \%$ \\
\hline 7. & $\begin{array}{l}\text { Pengoperasian aplikasi mudah } \\
8 .\end{array}$ & 4 & 5 & 1 & - & - & 43 & $86 \%$ \\
\hline Konsep latihan soal menarik & 5 & 3 & 2 & - & - & 43 & $86 \%$ \\
\hline 9. & $\begin{array}{l}\text { Suara ketika menjelaskan informasi } \\
\text { tentang objek tiga dimensi terdengar } \\
\text { jelas }\end{array}$ & 4 & 5 & 1 & - & - & 43 & $86 \%$ \\
\hline 10 & $\begin{array}{l}\text { Aplikasi berguna sebagai media } \\
\text { pembelajaran akademis dan non- } \\
\text { akademis }\end{array}$ & 4 & 5 & 1 & - & - & 43 & $86 \%$ \\
\hline & Jumlah & 39 & 45 & 16 & 0 & 0 & 423 & $84,6 \%$ \\
\hline
\end{tabular}

Keterangan:

Nilai Angka Penilaian = SS (5), S(4), N(3), TS(2), STS(1)

Total Nilai $=$ jumlah $($ Total jumlah responden yang memilih * nilai angka penilaian)

Index $\%=($ Total Nilai / skor maksimum $) * 100$

Skor maksimum (Per pertanyaan $)=10 \times 5=50$

Skor maksimum (Keseluruhan $)=100 \times 5=500$

Interval Penilaian :

Indeks 0\% - 19,99\% : Sangat Tidak Setuju

Indeks 20\% - 39,99\% : Tidak Setuju

Indeks $40 \%-59,99 \%$ : Netral

Indeks $60 \%-79,99 \%$ : Setuju

Indeks $80 \%-100 \%$ : Sangat Setuju

Hasil pengujian aplikasi pada 10 responden yang berpartisipasi dalam kuisioner Aplikasi AR Candi. Hasil yang didapatkan adalah nilai indeks $84,6 \%$ yang menandakan bahwa responden "Sangat Setuju" dengan keseluruhan pertanyaan yang diberikan.

\subsection{Pengujian Sudut}

Pada augmented reality, jarak merupakan salah satu faktor yang berpengaruh terhadap proses deteksi marker. Semakin jauh jarak marker terhadap kamera, maka semakin buruk kualitas pola marker yang dapat di proses oleh kamera pada aplikasi. Pengujian jarak ini bertujuan untuk mengetahui rentang jarak yang optimal agar marker dapat terdeteksi dengan baik.

Pengujian sudut dilakukan dengan 10 sudut, yakni $0^{\circ}, 10^{\circ}, 20^{\circ}, 30^{\circ}, 40^{\circ}, 50^{\circ}, 60^{\circ}, 70^{\circ}, 80^{\circ}, 90^{\circ}$ dengan jarak ideal $20 \mathrm{~cm}$. Tabel 4 menunjukkan pengujian deteksi marker berdasarka sudut yang sudah di tetapkan.

Uji coba marker dengan marker objek 3d menggunakan 10 sudut yakni Sudut $0^{\circ}$, Sudut $10^{\circ}$, Sudut $20^{\circ}$, Sudut $30^{\circ}$, Sudut $40^{\circ}$, Sudut $50^{\circ}$, Sudut $60^{\circ}$, Sudut $70^{\circ}$, Sudut $80^{\circ}$, dan Sudut $90^{\circ}$ dan menggunakan jarak ideal $20 \mathrm{~cm}$. Dengan hasil rentang
Sudut $0^{\circ}$ hingga Sudut $50^{\circ}$ marker dapat terdeteksi dengan cepat dan lancar, sedangkan untuk Sudut $60^{\circ}$ dan Sudut $70^{\circ}$ marker dapat terdeteksi namun sedikit melamban waktu pendeteksian oleh aplikasi, dan pada Tabel 4 Pengujian Sudut

\begin{tabular}{|c|c|c|c|c|c|c|c|c|c|c|}
\hline \multirow[t]{2}{*}{ No. } & \multirow[t]{2}{*}{ Candi } & \multicolumn{9}{|c|}{ Rentang Sudut } \\
\hline & & $0^{\circ}$ & $10^{\circ}$ & $20^{\circ}$ & $40^{\circ}$ & $50^{\circ}$ & $60^{\circ}$ & $70^{\circ}$ & $80^{\circ}$ & $90^{\circ}$ \\
\hline 1. & Singasari & $\checkmark$ & $\checkmark$ & $\checkmark$ & $\checkmark$ & $\checkmark$ & * & * & - & - \\
\hline 2. & Penataran & $\checkmark$ & a & $\checkmark$ & 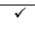 & $\checkmark$ & * & * & - & - \\
\hline 3. & Tegawangi & $\checkmark$ & a & $\checkmark$ & $\checkmark$ & $\checkmark$ & * & * & - & - \\
\hline 4. & Dadi & $\checkmark$ & 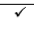 & $\checkmark$ & $\checkmark$ & $\checkmark$ & * & * & - & - \\
\hline 5. & Wringinlawang & $\checkmark$ & $\checkmark$ & $\checkmark$ & $\checkmark$ & $\checkmark$ & * & * & - & - \\
\hline 6. & Arimbi & $\checkmark$ & 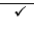 & $\checkmark$ & $\checkmark$ & $\checkmark$ & * & * & - & - \\
\hline 7. & Pari & $\checkmark$ & v & $\checkmark$ & v & $\checkmark$ & * & * & - & - \\
\hline 8. & Jawi & $\checkmark$ & a & $\checkmark$ & $\checkmark$ & $\checkmark$ & * & * & - & - \\
\hline 9. & Jabung & $\checkmark$ & a & $\checkmark$ & $\checkmark$ & $\checkmark$ & * & * & - & - \\
\hline 10. & Purwo & 2 & $\checkmark$ & $\checkmark$ & $\checkmark$ & $\checkmark$ & * & * & - & - \\
\hline
\end{tabular}

Sudut $80^{\circ}$ dan Sudut $90^{\circ}$ marker tidak dapat terdeteksi. Berhasil atau tidak nya marker di pindai tergantung oleh rating yang diberikan oleh vuforia saat mengupload target image, rating dinilai dari 1 hingga 5 dimana jika target image memiliki rating 0 , gambar marker tidak akan bisa digunakan, sedangkan semakin tinggi rating image target dari vuforia semakin cepat kamera menangkap marker yang di pindai dan juga dengan faktor pencahayaan untuk penerangan pada maker.

\section{KESIMPULAN DAN SARAN}

\subsection{Kesimpulan}

Setelah dilakukannya pembuatan dan pengujian aplikasi pengenalan candi-candi prasejarah pada Provinsi Jawa Timur Berbasis Augmented Reality Di Android, maka dapat ditarik kesimpulan sebagai berikut:

1. Hasil pengujian aplikasi pada 10 responden yang berpartisipasi dalam kuisioner Aplikasi AR Candi. Hasil yang didapatkan adalah nilai indeks 84,6\% yang menandakan bahwa responden "Sangat Setuju" dengan keseluruhan pertanyaan yang diberikan.

2. Marker berbentuk objek candi dengan 10 gambar candi dan setiap marker mempunyai gambar objek 3D yang sesuai.

3. Aplikasi dapat dijalankan pada sistem operasi Lolipop 5.1 dengan prosesor Mediatek MT6795 Helio X10 dan RAM 3 GB.

4. Pendeteksian marker dengan hasil rentang jarak $10 \mathrm{~cm}$ sampai $80 \mathrm{~cm}$ marker dapat terdeteksi dengan cepat dan objek muncul dalam satuan waktu 1 hingga 2 detik. Sedangkan pada rentang jarak $90 \mathrm{~cm}$ dan $100 \mathrm{~cm}$ marker tetap bias terdeteksi namun sedikit lebih lambat dalam memunculkan objek yang diperlukan waktu 3 hingga 5 detik. Kemudia pada rentang jarak 110 $\mathrm{cm}$ dan $120 \mathrm{~cm}$ marker $\neg$ tidak terdeteksi.

5. Marker dapat muncul pada cahaya yang dihasilkan dari lampu LED 3 watt, 5 watt, dan 30 watt. Marker dapat terdeteksi dengan baik pada lampu 
LED 5 watt dan 30 watt, sedangkan lampu LED 3 watt terdapat waktu delay dalam pemunculan objek.

6. Pendeteksian marker Sudut $0^{\circ}$ hingga Sudut $50^{\circ}$ marker dapat terdeteksi dengan cepat dan lancar, sedangkan untuk Sudut $60^{\circ}$ dan Sudut $70^{\circ}$ marker dapat terdeteksi namun sedikit melamban waktu pendeteksian oleh aplikasi, dan pada Sudut $80^{\circ}$ dan Sudut $90^{\circ}$ marker tidak dapat terdeteksi.

\subsection{Saran}

Berdasarkan peneltian yang telah dilakukan maka penulis dan peneliti dapat memberikan saran untuk pengembangan dan perbaikan kedepannya karena penelitian ini masih terdapat banyak kekurangan, sehingga perlu ada perbaikan sebagai berikut :

1. Desain objek 3D candi yang lebih detail sehingga lebih menarik.

2. Penambahan materi dalam bentuk video.

3. Penambahan texturing biar tampak lebih nyata objek candi 3D.

\section{DAFTAR PUSTAKA}

[1] bpcbjambi, (2014). Apa Itu Candi?. https://kebudayaan.kemdikbud.go.id/bpcbjambi/ apa-itu-candi/.

[2] Syahrin Alfi, Apriyani Meyti Eka, (2016). Analisis Dan Implementasi Metode Marker Based Tracking Pada Augmented Reality Pembelajaran Buah-buahan. Jurnal Ilmiah Komputer dan Informatika. Vol. 5, No. 1, Maret 2016 ISSN: 2089-9033

[3] Siswanti Sri Desy, Titoyan, (2016) Deteksi KeyPoint Pada Markerless Augmented Reality Untuk Design Furniture Room. Jurnal Komputer Terapan Vol 2 No 2 November 2016. ISSN: 2580-409X

[4] Pramono Anang, Setiawan Martin Dwiky, (2019). Pemanfaatan Augmented Reality Sebagai Media Pembelajaran Pengenalan Buah-Buahan. INTENSIF, Vol.3 No.1 February 2019. ISSN: 2580-409X

[5] Barkah Muhammad Avief, Rini Agustina, (2017). PEMANFAATAN AUGMENTED REALITY (AR) SEBAGAI MEDIA PEMBELAJARAN INTERAKTIF PENGENALAN CANDI - CANDI DI

\section{MALANG RAYA BERBASIS MOBILE} ANDROID

[6] Novitasari (2019) Aplikasi Pengenalan Senjata Tradisional Indonesia Menggunakan Augmented Reality Berbasis Android JATI (Jurnal Mahasiswa Teknik Informatika) Vol 3 No 2 September 2019

[7] Apriyani Meyti Eka, Gustianto Robie. 2015 Augmented Reality sebagai Alat Pengenalan Hewan Purbakala dengan Animasi 3D menggunakan Metode Single Marker. Jurnal Infotel Vol.7 No.1 Mei 2015. ISSN : 2085-3688

[8] Ilham Efendi. Di akses 13 Januari 2020, Pengertian Augmented Reality(AR). https://www.it-jurnal.com/pengertian-augmentedrealityar/

[9] Achmed Islamic Hernawan. (2018), Apa itu Android? Penjelasan Super Lengkap Android Ada Disini!, https://windowsku.com/apa-ituandroid-adalah/

[10] Auliasari, Orisa. 2015 Pengembangan Aplikasi Baby Care Menggunakan Metode User-Centered Design

[11]Perwitasari Ika Devy, (2018) Teknik Marker Based Tracking Augmented Reality Untuk Visualisasi Anatomi Organ Tubuh Manusia Berbasis Android

[12] Ramdhan Khemal Rizky, Nurhasanah Youllia Indrawaty, Utoro Rio Korio. Aplikasi Media Pembelajaran Tulang Manusia Menggunakan Augmented Reality (AR) Berbasis Android. Jurnal Teknik Informatika dan Sistem Informasi Vol. 3 No.3. 2443-2229

[13] Asrin Simulasi Digital : Makalah Aplikasi Blender https://www.academia.edu/12120254/Simulasi_D igital_Makalah_Aplikasi_Blender

[14] Andriyat Rio (2018). Pengenalan 3D Unity. https://staff.uniku.ac.id/rioandriyat/pengenalan3d-unity/

[15] Anonymous. (2017). Pengertian Flowchart Dan Jenis-Jenisnya.

https://informatikalogi.com/pengertian-flowchartdan-jenis-jenisnya/

[16] T.M. Rita Istari. 2015. RAGAM HIAS CANDICANDI DI JAWA Motif Dan Maknanya. Yogyakarta. Kepel Press. 